\title{
Juri Lotman on proper name
}

\author{
Ülle Pärli, Eleonora Rudakovskaja \\ Department of Semiotics, University of Tartu, \\ Tiigi 78, Tartu 50410, Estonia \\ e-mail: ylle1sem@ut.ee,elja@ut.ee
}

\begin{abstract}
The article treats the concept of proper name in Juri Lotman's semiotics, taking into account also studies in the same field by other authors of the Tartu-Moscow school (V. Ivanov, B. Ogibenin, V. Toporov, B. Uspenski). Focus is laid at three sub-topics: name and myth, name and text, name and artistic creation. One of the sources of treating proper name for both the program article by J. Lotman and B. Uspenski ("Myth - Name - Culture"), and works by several other semioticians of the Tartu-Moscow school is confidence in the connection between proper name and mythical (a-semiotic) thought: semiosis equals here with nomination. Proper name plurality, different re-namings affirm the continuing importance of mythical thinking in later culture. Proper names (such as personal names, place names) belong, in addition to natural language, also into a certain individual system, forming thus an interlinguistic layer located on the boundary of language. J. Lotman stresses that art has a specific power of uniting general and proper name (proper name characterized here by individuality, explosiveness). An artistic work is even doubly of proper name character: both the act of creation and its reception are by nature individual and unrepeated. In the opinion of the authors the treatment of proper name by the Tartu-Moscow school contains fruitful and promising standpoints for the analysis of contemporary culture that, however, have been applied unjustifiably little.
\end{abstract}

Lotman has turned to the topic of proper name in his works written at different times. Just as it is characteristic of Lotman's research method, proper name as a research object obtains a new meaning according to the context it is being inspected in and how it relates to the whole set of problems that is important for Lotman at a current moment. In Lotman's works the approach to the topic of proper names always remains particular and it is difficult to set it in the context of traditional logico-semantic studies. Though at the same time, and in 
spite of being expressed in another conceptual system and from a specific viewpoint, Lotman's statements have touchpoints with, e. g., German logico-semantic scientific tradition (Frege, Wittgenstein, Cassirer's myth treatment). However, this theme definitely deserves special treatment that extends the frames of the current presentation. In this paper the concept of the name in Lotman's semiotics will be analysed in the context of other authors of the Tartu-Moscow school (V. Ivanov, B. Uspenski, V. Toporov, B. Ogibenin).

J. Lotman's conception of the proper name so as he has put it down with Uspenski in the article dating back to 1973 and entitled as "Myth name - culture" is primarily connected with a certain kind of thinking, i.e. with mythical thinking and consciousness that must by its characterisation also provide with a better opportunity to understand peculiarities of poetic language. This is actually natural, since during exactly these years — in the beginning of the 70s — Lotman had elaborated a systematic treatment out of the semiotics of literary text.

The main standpoints of the mentioned article in a way conclude results of research on relations between the proper name, nomination, word and object that were carried out already during the 1960s by authors of the Tartu-Moscow school. This concerns especially examination of proper name in connection with myth and proper names as a specific differently organised system inside the language system.

\section{Proper name and myth}

In the mentioned work by J. Lotman and B. Uspenski, "Myth name - culture" (Lotman, Uspenski 1992: 58-75), proper name is viewed as a bearer of mythological consciousness, and mythological object description, in its turn, is thereby given to the metalinguistic description via opposing. Thus proper name is understood through the traditional opposition logos/mythos, and equalised (with certain reservations) with one of these alternatives.

Myth and name are mutually conditioned: myth is personal (nominated), whereas name is mythological. Semiosis is here equalised with nomination. Thus: 
Mythological; description of an

object by proper name

metatextual

monolinguistic

understanding, recognition

mythological untranslatable thinking semiosis $=$ nomination

mythical thinking operates with the hierarchy of objects themselves nonconventionality of proper names a-semioticalness

equalisation of word and denotation
Non-mythological;

logical

metalinguistic

polylinguistic

description and interpretation translation

semiosis

logical thinking operates with words

Mythical name opposes also the metaphor: according to the authors the latter is, strictly speaking, impossible in mythical text, just as synonymy as such is impossible in mythological equalisation. Referring to M. Altman's treatment of connections between myth and homonym it is stressed that while poetry is connected with synonymy, mythology realises itself through the contradictory linguistic phenomenon - the homonym. From this arises a conclusion about the contradiction of poetry and myth, and about poetry's impossibility on the mythological level (which of course does not exclude a mythical element in poetry). "Poetry and myth are as if antipodes, neither is possible without the other" (Lotman, Uspenski 1992: 72-73). Dissolution of mythical consciousness stands indeed in resemantisation of mythological texts as metaphoric in the developmental course of synonymy. Separation of a word from a thing is a precondition for the emergence of poetry. Free word opposes proper name as a bound word. Poetic thinking thus covers the intermediate zone in-between the mythological and the logico-scientific.

As a conclusion, the authors formulate that:

From the semiotic aspect the durability of mythological texts can be explained so that, having been given birth by a specific nominative semiosis - when signs are not assigned, but recognised and nomination act itself equalises with the act of cognition - during later historical development myth became to be understood as an alternative to thinking in signs. (Lotman, Uspenski 1992: 69)

Thus proper name connects with a certain - mythological - consciousness, way of thinking (this conception is very close to J. Meletinski's description of mythological consciousness (Meletinski 1995)), that in turn allows Lotman to apply the feature of "proper nameness" 
as a parameter in cultural typology (cultures oriented to mythical thinking - cultures oriented to non-mythological thinking).

Such a view on proper name, nomination is traditional for studies of the Tartu-Moscow school. The most direct treatment is given to the theme of name in Indo-European comparative studies, attempts to reconstruct the primary myth and working out a relevant methodology. The origin of name and establishment of name were questions the answers to which were searched for in the archaic texts of the Tartu-Moscow school (cf., e.g., Ivanov 1964; Ogibenin 1966; Ivanov, Toporov 1974).

In treatments of connections between myth and name an important predecessor was thereby O. Freidenberg (just as well as representatives of the school of historical poetics, A. Vesselovski and A. Potebnja). So has O. Freidenberg described exactly invocation, naming, calling by name, incantation as the most archaic ritual. "Their foundation is the effect of name: in archaic marriage and funeral customs we find a honoured god - calling the protagonist out by name, i.e. the act of re-creation of the inner nature that exists in his name" (Freidenberg 1997: 96). Similarity as a main category of the archaic consciousness is revealed by speech act repeating behavioural act, name is similar to the inner nature, calling by name reanimates the inner nature of the primordial man (Freidenberg 1997: 97).

In V. Ivanov's opinion, in the myth there are expressed ancient, presemiotic imaginations about the relationships between the name and the object. So, for example, when comparing Rigveda's hymns, the author finds that while different objects were named here by men as the first of the wise who were under the protection of god, the Master of speech, then gods were named by the Master of speech himself. Ivanov also points out that in Plato's dialogues Kratylus and Charmides in which the topic of name is overwhelming, an alike mythological figure bearing the onomatic/onomatological function appears. Ivanov suggests that the topic of sameness of a name and its giver that is reflected in mythopoetic texts precedes semiotic discussions on the signifier and the signified of the linguistic sign of later centuries (see Ivanov 1998: 609). On the basis of Rigveda, B. Ogibenin assures in a study dedicted to Veda's onomastics, equalisation of the nature of a name and name giver, a certain correspondence between the structure of names of Veda's gods and the structure of god (denotation) as an element of Veda's pantheon that is characteristic of later brahmanistic texts. The author also indicates an ety- 
mological kinship of word stems bearing such meanings as to "set", to "give name", to "name", to "create" (Ogibenin 1966: 218).

In connection with differentiating between Rigveda's proper names another important methodological problem arises: how to distinguish between proper names in archaic texts, how to tell proper names from general names in Veda texts, when god's name equalises with his functions. Boundaries between them are vague and the usual differentiation criteria valid in language are here probably insufficient. This, in turn, affirms statements on mythical thinking as based on proper names outlined in Lotman's and Uspenski's article. "Studies in slavic antiquities" by V. Ivanov and V. Toporov (1974) also demonstrates this archaic syncretistic connection between general name and proper name.

An output of a certain tendency of mythologisation that always goes on in culture are, for example, re-naming, belief in that together with a new name new fate is obtained; the switch of general names to the sphere of proper names that can be approached as expansion of mythological consciousness (that can be compared with Frege's description of the emergence of such pseudo proper names as "public will").

Proper names as inherently non-signs should thus compose a certain non-semiotic zone in culture. As put by Lotman and Uspenski:

In certain linguistic situations the behaviour of proper names is so different from the behaviour of words belonging to other linguistic categories that it inevitably leads to a thought that we are dealing with a certain other language ordered in another way, having however been incorporated into natural language. (Lotman, Uspenski 1992: 62)

What composes the proper name continuum of language and what is its position in text, in culture understood as text? Answers to these questions can be searched for at best from V. Toporov's works. His studies dedicated to toponomastics provide perhaps, so as based on the general views of the Tartu-Moscow school, the best comprehension of the treatment of proper name as a certain class of linguistic elements.

\section{Proper name and text}

First, what have been viewed as proper names, just as well as like in Lotman's works, are proper names functioning as such in ordinary language (e.g., personal names, place names). Toporov admits thereby 
that for formal logic the extension of proper name is purposeful, switching into them also names possessing a relevant structure of signifying an object. Here the author refers to R. Carnap's and G. Frege's works as fruitful approaches to proper name in semanticlogical analysis. At this point it can be indicated that for example for G. Frege proper name is any name (a word, sign, complex sign) signifying a certain object, not a notion or relationship (Frege 1999: 27).

Asserting that proper names are characteristic solely of human socium, that in language they form the part necessarily participating in the formalised language of logic, and that the proper name variety testifies the level of differentiation and compositional structures of a human community itself (Toporov 1962: 3), the author at the same time pays attention to a certain feature of the proper name being a boundary phenomenon in relation to any system of natural language. In Toporov's opinion in cases proper names appearing in texts we are dealing with the so-to-speak intermediary elements so as compared with the system of ordinary language and the so-called "hieroglyphic" elements among which there belong e.g. certain symbols, abbreviations and foreign words that function in the frame of a given text as particular idioms. On the one side proper name is characterised by certain grammatical parameters of natural language (in extreme cases proper name may completely switch into the system of a given language), and on the other - they are connected with the "hieroglyphic" elements by the fact that for proper name a concrete given text is not, as a rule, primary (for topographic names such an "own" text can be e.g. a map). Thus, as a rule, proper name belongs into its own system and grammatical, even lexical description can not be the only ones for it.

Proper names thus form a particular interlinguistic layer in language; Toporov compares this to music or fine arts. Therefore they are very important also as an intercultural communication channel both in time and space (Toporov 1962: 5).

J. Lotman, in turn, has assigned the role of such a communication channel to the symbol. The proximity of the symbol in thus function to the proper name stands already in the fact that in culture they form a specific archaic layer that, so as compared with ordinary language, is difficult to describe as a system. In the case of proper name Toporov has stressed its syntactic independence:

[...] the independence of proper name from textual elements [is revealed] already by that proper names use only a limited part of linguistic grammatical 
possibilities (or at least not all the possibilities), thereby this part does not completely coalesce with what is grammatically allowed for other elements of a text in the language of a given period. Besides that it is noteworthy that in texts claimed primary for proper names, syntax is built quite differently from an ordinary text. This peculiarity is best illustrated by the syntax of toponymies in a geographic map or a sketch in which it is 'multidimensional' (at least by no means linear). It must be taken into account that the syntactic sphere of proper name is usually very limited, but this in turn makes the toponymic — and more generally the toponomastic — space discrete. (Toporov 1962: 5)

Alike features are outlined by Lotman at the description of the position of symbol in culture. A symbol may not switch into a syntactic chain, and even if it does switch, it thereby preserves semantic and structural independence.

It is simple to withdraw it from a semiotic context, and it switches into another textual environment just as simply. An important feature of it is connected with that: a symbol does not belong into a certain crosscut of culture, but it cuts vertically through that crosscut, coming from the past and heading towards the future. The memory of a symbol is always older than the memory of the non-symbolic context surrounding it. (Lotman 1992: 192)

Lotman stresses that, condensing different principles of signification, a symbol simultaneously leads outside the sphere of signs. It mediates between different spheres of semiosis, just as well as between the semiotic and non-semiotic spheres, between the textual synchrony and cultural memory. Symbol, not being homogeneous with the textual space surrounding it, is as if a deputy of other cultural epochs, a reminiscent of the ancient (= "eternal") foundations of culture (Lotman 1992: 198).

The above mentioned alike features do not exclude the essential difference, maybe even contradiction, between proper name and symbol. Symbol is the richer the more it "remembers", or in other words the more a symbol remembers, the more symbol it is. At the same time proper name is the more a proper name the less it "remembers", or the more it is simply a "denominator"/name giver. Toporov has stated that the less a proper name is motivated, etymologised, the less it carries additional information, the stronger is its "naming" function, "the more strongly proper name's feature of 'being a proper name' is revealed" (Toporov 1962: 8). Minimal motivation appears when a speaker is unaware of the actual denotation or when a known denotation bears possibly incomprehensible name unmotivated by internal form or analogous formations. Thus the contradiction 
between proper name and symbol is appended by their function of taking mutually over each other's functions. Proper name then acts as a symbol and an unrecognised symbol as a proper name.

In social circulation the "naming" function of proper name weakens due to that the name obtains certain evaluative features, contains information about name bearer's social status, etc. B. Uspenski calls these processes "spontaneous semiotic differentiation of name" (Uspenski 1994: 152). In works by V. Toporov, J. Lotman, B. Uspenski, and other semioticians of the Tartu-Moscow school one can find numerous examples on how proper names that are called into being only to name, not to mean, in culture turn into meaningful.

Thus it can not be maintained that "proper name language" lies outside semiosis. While by Lotman proper name language that bears mythical consciousness belongs to the sphere of the "other" or the "alien" semiotics, it still participates in semiotic processes, because it is exactly the border of the semiosphere as a semiotically active area that the processes of "metaphoric translation" are going on. A comparative standpoint can be found in Frege's work who characterises proper name by its reference to a specific object. Frege, however, stresses the one-sided light of the proper name, the oscillation of its meaning at the same reference that together with subjective imagination makes proper name semiotically productive (Frege 1999: 24). (Similar standpoints can be found also in Barthes' treatment of denotation and connotation.)

\section{Proper name and poetry/creation}

Among lines about myth Lotman has stressed that its reading from the standpoint of later semiotic consciousness results in metaphoric constructions. Here we find also a statement according to which,

In a number of cases mythological text, having been translated into the categories of non-mythological consciousness, is perceived as symbolic. A symbol of this type can be interpreted as reading a myth from the standpoint of later semiotic consciousness, i.e. reinterpreted as an iconic or quasi-iconic sign. (Lotman, Uspenski 1992: 67-68)

We can see that the symbolic meaning of a text understood this way is close to the metaphorical. The area in which the above mentioned notions - proper name, symbol, metaphor - approach each other, is indeed artistic creation. 
For Lotman the topic of proper name remains bound with the need to understand the nature of aesthetic sign and artistic language. In an explosive model of culture (Culture and Explosion) proper name has clearly been dealt against the background of general name. Here proper name signifies the individual, personal, unpredictable. Lotman compares the world of proper names in its intimacy to the idea of the cosmic motherly womb. Proper name and general name are as if two registries that are united in their conflict. "The real speech flows freely from one sphere to the other, but the spheres do not melt into each other. On the contrary, by this their contrast is brought forward all the more" (Lotman 2000a: 104). Lotman writes: "Neither the world of proper names nor the one of general names can, if taken separately, include the world. We perceive reality through the dialogue of the two and this is one aspect making art inescapable" (Lotman 2000a: 119).

It is exactly individuality, choice that presumes the existence of space filled with proper names. The individual ad hoc created inherently metaphoric word, so as opposed to the general word, generates new meaning (thus proper name and metaphor do not oppose each other any more).

As known, the article "Myth — name — culture" was introduced by the statements "the world is substance" and "the world is a horse" whereby the first is an example of metalinguistic description and the latter illustrated such a definition of the object which is characteristic of mythological thinking that processes through an original object located on a hierarchically higher level. If we tried to bring an example of a later position, it probably would be enough to re-locate the second statement into the context of a poem where it would turn into an individual image in which the stated equality is not absolute any more. Poetic context excludes absolute tautology.

In connection with the above said, the notion of isomorphism obtains a new meaning. Earlier we talked about such isomorphism that is characteristic of mythical thinking and that exists between described world and descriptive language (between object and word). Let us remind that one of the most important feature of mythical consciousness and the proper name bearing it is isomorphy of the name and the object that thus should characterize the relevant asemiotic area. Lotman brings isomorphism forth also in the semiosphere, but this is the so-called vertical isomorphism that rules between structures located on different hierarchical levels. So the emergence of new texts presupposes surpassing this isomorphism: the most simple condition for semiosis is that the substructures participating in it do not have to 
be isomorphic with each other, but that each must be isomorphic with a third element that is located on a higher level representing the system they belong to.

For example in the article "Culture as a subject and an object for itself" Lotman speaks about structural isomorphism between parts and the whole of semiosphere and between semiotic monads and semiosphere (Lotman 2000b: 639-647). Can we see here certain signification of the mythological element in the very conception of the author himself? Can we see here myth and art coming closer that amongst others is expressed also in the understanding of proper name? Compare, for example, the following statements:

[...] 'the proper name language' and the mythological thinking connected with it impelled the power to apply similarities, analogies and equivalencies. [This advanced the idea of isomorphism that is] one of the leading conceptions both in contemporary mathematics and science in general. ("Myth name — culture", Lotman, Uspenski 1992: 74-75).

The influence of art lays in our power to perceive the dissimilar as the similar, to replace on the one hand the dissimilarity relations and on the other hand the similarity relations with the relations of isomorphism. [This turns art into] the supreme power of perception - the highest peak man can rise by possessing the hidden secrets of worlds surrounding him. ("The role of art in cultural dynamism", Lotman 1995: 22)

Hereby, when comparing with the article "Myth - name - culture", also innovative presentation of the problem of translatability and untranslatability is interesting. As remembered, for mythological consciousness translation is impossible, naming one thing in different ways is not possible without changing its essence. Lotman has frequently stressed the untranslatability of a literary text also from the aspect of the unity of the plane of content and expression. At the same time, when describing creative inspiration as an unpredictable moment of explosion, he writes about turning the untranslatable into the translatable: such a moment of explosion "makes the incompatible adequate, the untranslatable translatable" (Lotman 2000a: 29).

At the same time explosion does not create synonyms. Taken separately, this statement would contradict stressing the importance of the role of synonym at the emergence of free word and poetry. Inasmuch as in Culture and Explosion synonym obtains a conditional meaning, it rather opposes the original thought, the individual nonrecurrent thought: 
From the viewpoint of a given culture creation of no writer can be a synonym of another (at least while we are dealing with original creation). Every of them means an independent, individual and unique path. This does not exclude their involvement in some generalising categories. (Lotman 2000a: 118)

In arts, Lotman's general viewpoint imposes a proper name meaning also on the pronoun "I". Here we can detect also certain polemics with statements referred to in R. Jakobson's article "The poetics of grammar and the grammar of poetics", and via Jakobson's article taking up a more general position in connection with as important a theme for Lotman as unique cultural practice and its generalising description, relations between the individual and the general. As known, in this article Jakobson cites, amongst others, also Stalin who writes about grammar in comparison with geometry that, abstracting from the individual and concrete, creates general laws and rules (cf. Lotman's example of the relationship between general and proper names describing a general talking about his soldiers, whereby the relatives, their own family has but a proper name without plural for them). From this standpoint pronouns are all over grammatical, relational, differing thereby from other words of autonomous nature. Words being and not being pronouns relate as if bodies of geometric and non-geometric nature. Jakobson observes that the function fulfilled by grammar in poetry is comparable with the function of geometry in fine arts. $\mathrm{He}$ demonstrates, via the analysis of "grammatical figures", how grammar may turn into a unique artistic means of expression in a poetic text (Jakobson 1981: 75-78).

Lotman makes a distinction between the pronoun "I" and the "I" as a proper name cultural phenomenon.

Thereby the structure of the pronoun "I" is much simpler, while the proper noun "I" is not a clearly definable linguistic sign. Its nature is best revealed in art:

Art is the most developed space of conditional reality. Exactly this makes it a "practice ground" of mental experiment and processes of intellectual dynamism in general. In connection with this we are interested in the power of art to connect the spaces of proper and general names. Whole wide areas of art the roots of which reach the most archaic layers are connected with the first person and represent the Ich-Erzählung - the narrative of the first person. However, at the same time this " $\mathrm{I}$ " occurs to be the bearer of the sense "any other in my shoes'. (Lotman 2000a: 40)

From here we reach a central theme in Lotman's later works - the role of individual consciousness in cultural processes, and on the other hand - understanding cultural explosion moments through mecha- 
nisms of individual meaning generation. While cultural explosion is connected exactly with the world of proper names, the world of general names in which elements are replaceable is more connected with continuing processes.

Thereby the explosive developments going on in art differ by nature from, e.g., scientific discoveries. At the description of the explosiveness of scientific discoveries, Lotman's viewpoint is similar to the way this problem was risen in phenomenological treatment, e.g., in Husserl's The Beginning of Geometry later amplified by Derrida (Husserl 1996). This is a question about the beginning of the general idea as it is first given in the consciousness of the creator, about the transformation of the unique into invariable. Husserl has written that "The Pythagorean theorem, like geometry, exists only once, be it however much expressed in different languages" (Husserl 1996: 215).

Against this background, for Lotman art is doubly proper name by nature: it is no only the act of creation, but also reception of an artistic work that has the essence of proper name. A literary work preserves, or more correctly reanimates its uniqueness in every act of reading. For example, when reading a novel, the reader enters the world of proper names perceived intimately.

An artistic text turns this tendency into one of its most important structural element. It forces us to perceive any space as the space of proper names. We fluctuate between the subjective world known to us personally and its antithesis. In the artistic world the "alien" is always the "own", while at the same time the "own" is "alien". (Lotman 2000a: 105)

Lotman illustrates this peculiarity of art by the example of the novel. The novel creates the space of the so-called third person. By its linguistic structure it is given as located objectively outside the world of both the author and reader. However, at the same time, for the author, this world is lived as the one created by him/her, it is intimate, just as well as it is lived for a reader. Thus the "third person" in a novel obtains the emotional aureole that of the "first person". In the case of artistic text the message is relocated from the world of general names into the world of proper names (ibid., 105).

We dare to maintain that Culture and Explosion, called by Lotman also his mental testament, is a very personal book. In spite of its rich historical material it is simultaneously Lotman's reflection on his participation as a thinker in his contemporary cultural processes. Lotman's individual, personal thinking and experience, and its relation to the previous tradition and to the scientific thought emanating from 
himself are comparable to the connection an artist creates between the space of proper and general names. At the same time it may be that Culture and Explosion, being centered at the proper name, makes it to a certain degree critical of semiotics. Yet semiotics deals, as a rule, with models organising reality and with self-descriptions assembling the diversity of life into an invariant. As stressed by Lotman, this is the basis on which his own culturo-typological descriptions have been created. In Culture and Explosion he tries, more than ever before, to bring closer together his approach to cultural processes as a historian and literary scholar (i.e. what pertains to proper names) on the one hand, and a semiotician (i.e. what pertains to general names) on the other. Maybe it is this why book can be called his mental testament. The present article aimed not so much at giving a thorough overview of the topic of proper names, as at pointing at the need to re-read works by Lotman and other authors of the Tartu-Moscow school in order to bring forward those potentialities and trends of thought that may sound surprisingly contemporary in today's cultural thought following poststructuralism. The authors are convinced in that treatments of proper names are one of the most perspective analytic keys to understand contemporary world, allowing to treat this topic much more flexibly than e.g. views emanating from Barthes' "contemporary mythology". Also it is exactly Lotman's relevant works that open novel possibilities to understand the nature of art and its inevitable integrity.

\section{References}

Frege, Gottlob 1999. Tähendusest ja osutusest. In: Kangilaski, Jaan; Laasberg, Margo (eds.), Tähendus, tõde, meetod: Tekste analüütilisest filosoofiast. Tartu: Tartu Ülikooli Kirjastus, 22-77.

Freidenberg, Olga 1997 = Фрейденберг О. М.. Поэтика сюжета и жанра. Москва: Лабиринт.

Husserl, Edmund 1996. = Гуссерль, Э. Начало геометрии. (Введение Жака Деррида). Москва: Ad Marginem.

Ivanov, Vjatsheslav 1964. = Иванов, В. В. Древнеиндийский миф об установлении имен и его параллель в греческой традиции. In: Струве, В.В. (ред.), Индия в древности. Москва: Наука, 85-94.

- 1998 = Иванов, В. В. Очерки по предыстории и истории семиотики. In: Иванов, Вяч Вс., Избранные труды по семиотике и истории культуры. 1 . Москва: Школа «Языки русской культуры», 605-811. 
Ivanov, Vjatsheslav; Toporov, Vladimir 1974 = Иванов, В. В.; Топоров, В. Н., Исследования в области славянских древностей: Лексические и фразеологические вопросы реконструкиии текстов. Москва: Наука.

Jakobson, Roman 1983. Поэзия грамматики и грамматика поэзии. In: Jakobson, Roman, Selected Writings, 3. The Hague: Mouton Publishers, 63-86.

Lotman, Juri 1995 = Лотман, Ю. М. Роль искусства в динамике культуры. In: Песонен, П. И др. (ред.), «Свое» и «чужсое в литературе и культуре. (Studia russica helsingiensia et tartuensia, 4.) Helsinki: Helsinki University Press, 9-24.

- 2000а = Лотман, Ю. М. Культура и взрыв. In: Лотман, Ю. М., Семиосфера. Санкт-Петербург: Искусство-СПБ, 12-148.

- 2000b = Лотман, Ю. М. Культура как субъект и сама-себе объект. In: Лотман, Ю. М., Семиосфера. Санкт-Петербург: Искусство-СПБ, 639647.

Lotman, Juri; Uspenski, Boriss 1992 = Лотман, Ю. М.; Успенский, Б. А. Миф - имя - культура. In: Лотман, Ю. М., Избранные статьи 1. Москва: Александра, 58-75.

Ogibenin, В. $1966=$ Огибенин, Б. Л. Вопросы ведийской ономастики (собственные имена в “Ригведе".). In: Иванов, В. В. (ред.), Структурная типология языков. Москва: Наука, 216-224.

Toporov, Vladimir 1962 = Топоров, В. Н. Из области теоретической топономастики. Вопросы языкознания 6: 3-12.

- 1995 = Топоров, В. Н. Петербург и "Петербургский текст русской литературы" (введение в тему). In: Топоров, В. Н., Миф. Ритуал. Символ. Образ. Москва: Прогресс, 259-367.

Uspenski, Boris 1994a = Успенский, Б. А. Мена имен в России в исторической и семиотической перспективе. In: Успенский, Б. А., Избранные труды, 2. Москва: Гнозис, 151-163.

- $1994 \mathrm{~b}=$ Успенский, Б. А. Социальная жизнь русских фамилий. In: Успенский, Б. А., Избранные труды, 2. Москва: Гнозис, 164-204.

\section{Имя собственное у Юрия Лотмана}

В статье рассматривается концепция имени собственного в работах Ю. М. Лотмана в контексте соответствующих разработок других исследователей Тартуско- Московской семиотической школы, — таких как В. В. Иванов, Б. Л. Огибенин, В. Н. Топоров, Б. А. Успенский. Статья делится по проблемам изучения на подразделы имя и миф, имя и текст, имя $u$ художественное творчество.

Одним из основных положений при рассмотрении имени собственного в трудах названных авторов является его связь с мифом, мифологическим (не- или досемиотическим) мышлением. Оно легло и в основу програмного для нашей темы исследования Ю. М. Лотмана и Б. А. Успенского "Миф - имя - культура". Богатство сферы имен собствен- 
ных, разнообразные переименования в более поздней культуре свидетельствуют о значимости в ней мифологического элемента. Имена собственные входят кроме естественного языка еще в свою собственную систему и тем самым образуют в нем пограничную зону, которую В. Н. Топоров рассматривает как интерлингвистическую по своей природе. Ю. М. Лотман в своих более поздних работах особо подчеркивает способность искусства объединять сферы имен собственных и нарицательных (имя собственное означает здесь индивидуальное, неповторимое начало, с ним связан культурный взрыв). Не только акт творения, но и акт восприятия произведения искусства индивидуален и неповторим, т.е. обладает природой имени собственного. По мнению авторов настоящей статьи теоретические положения Ю. М. Лотмана и других ученых Тартуско-Московской школы по проблемам имени могут оказаться неожиданно плодотворными для описания сегодняшней культурной ситуации.

\section{Juri Lotman pärisnimest}

Artikkel käsitleb pärisnime kontsepti Juri Lotmani semiootikas, arvestades ka teiste Tartu-Moskva koolkonna autorite (V. Ivanov, B. Ogibenin, V. Toporov, B. Uspenski) selleteemalisi uurimusi. Keskendutakse kolmele alateemale: nimi ja mü̈̈t, nimi ja tekst, nimi ja kunstilooming.

Üheks pärisnime käsitluse lähtekohaks nii J. Lotmani ja B. Uspenski programmilises artiklis "Müü - nimi — kultuur" kui mitmete teiste TartuMoskva koolkonna semiootikute töödes on arusaam pärisnime seotusest müüdilise (asemiootilise) mõtlemisega: semioos võrdub siin nominatsiooniga. Pärisnimeline mitmekesisus, erinevad ümbernimetamised annavad tunnistust müüdilise mõtlemise jätkuvast osatähtsusest hilisemas kultuuris. Pärisnimed (nagu isiku-, kohanimed) kuuluvad peale loomuliku keele veel teatud oma süsteemi, moodustades seega keele piirialale jääva interlingvistilise kihistuse. J. Lotman rõhutab, et kunstil on eriline võime ühendada eneses üld- ja pärisnimelisust (pärisnimeline on siin mõistetud kui individuaalne, plahvatuslik). Kunstiteos on isegi topelt pärisnimeline: nii loomeakt kui teose vastuvõtt on oma olemuselt individuaalsed ja kordumatud. Artikli autorite arvates sisaldab Tartu-Moskva koolkonna pärisnime-käsitlus seni põhjendamatult vähe rakendatud viljakaid ja perspektiivseid seisukohti tänapäeva kultuuri analüüsiks. 